\title{
Suillus grevillei and S. clintonianus (Gomphidiaceae), two boletoid fungi associated with Larix
}

\author{
MAURI KORHONEN, JAAKKO HYVÖNEN and TEUVO AHTI
}

\begin{abstract}
KORHONEN, M., HYVÖNEN, J. \& AHTI, T. 1993: Suillus grevillei and S. clintonianus (Gomphidiaceae), two boletoid fungi associated with Larix. - Karstenia 33:1-9. ISSN 0453-3402

Suillus clintonianus (Peck) Kuntze, earlier regarded as a dark red-brown form of $S$. grevillei (Klotzsch: Fr.) Singer, is shown to possess other distinctive morphological characters as well, and to have a wide distribution in Eurasia and North America. It is here proposed as a separate species. Both $S$. grevillei and $S$. clintonianus are ectomycorrhizal fungi of Larix, and often grow together, but the total distributions are different. S. grevillei f. badius (Singer) Singer is included in S. clintonianus.
\end{abstract}

Key words: Boletes, Finland, Larix, Suillus, taxonomy

Mauri Korhonen, Botanical Museum, P.O. Box 47, FIN-00014 University of Helsinki, Finland

Jaakko Hyvönen and Teuvo Ahti, Department of Botany, P.O. Box 47, FIN-00014 University of Helsinki, Finland

\section{Introduction}

The pilei of the widespread bolete Suillus grevillei (Gomphidiaceae) range in colour from light lemon yellow to dark reddish-brown. $\mathrm{Al}$ though this variation is generally recognized, it is usually interpreted as an infraspecific variation not deserving of taxonomic recognition (e.g. Slipp \& Snell 1944, Smith \& Thiers 1964, Watling 1970). This view has been supported by the observation that dark reddish-brown and the normally light yellow pilei are sometimes found at the same site. Further corroboration is provided by the observation that a dark reddishbrown "form" is prevalent in the Russian Far East and gradually the "typical" yellow $S$. grevillei becomes more common as one approaches Europe (K. Kalamees, pers. comm.). A similar trend has been noted in North America, where the yellow form is replaced by the dark reddish one in the western part of the continent (Miller 1978). The reddish variant has occasionally been recognized at varietal level, e.g. as S. grevillei "var. badius Singer" (e.g. Kallio \&
Heikkilä 1992), but generally it has been ignored.

In Finland, especially in the northern parts of the country, the two colour variants frequently grow together. They are easily distinguished in the field and microscopic studies reveal additional, essential differences, as described below. We are therefore proposing that the two variants be recognized as distinct species, $S$. grevillei and S. clintonianus.

\section{Material and methods}

Most of the material was collected in Finland. Many of the specimens were photographed at the original site. In addition, herbarium material from various countries was studied, both material deposited Helsinki $(\mathrm{H})$, and material from other herbaria (C, K, LE, NYS, OULU, S, TUR, TURA, UME, UPS, VPI).

The microscopical study of specimens was done with a Leitz Dialux microscope equipped with a Pl Apo Oel 100/ 1.32 oil immersion lens. Spores, cystidia, pileipellis, etc. were drawn with a Leitz drawing tube at a magnification of 2000 . All measurements are based on the drawings.

All the preparations were mounted in pure water without use of any softening or colour media. This allowed 
observation of the natural colour of the structures. The ratio of length to width was measured in individual spores, and the mean spore volume was calculated according to the formula of an ellipsoid: $4 \pi / 3 \mathrm{abc}$ (Breitenbach \& Kränzlin 1991). The spore volume was based on the material as cited in Fig. 6.

\section{Suillus grevillei - Figs. 1, 2, 5a-d, 6}

Suillus grevillei (Klotzsch : Fr.) Singer, Farlowia 2:259. 1945. - Boletus grevillei Klotzsch, Linnaea 7:198. 1832, 'grevillii': Fr., Syst. Mycol. 3 (Index) 59. 1832, nom. superfl. for Boletus flavus With. 1792, but because sanctioned, not automatically typified by that name (Art. 7.13). - Type: Sine loco, Herb. Klotzsch (K!; lectotype by Singer, see Palm \& Stewart 1986: 327).

Boletus flavus With., Bot. Arr. Brit. Pl. 3:415. 1792. Suillus flavus (With.) Singer, Farlowia 2:260. 1945. Type: [England], Bolton, Hist. Fung. Halifax 4: Tab. 169. 1792 (lectotype, by Dörfelt 1984: 61).

Boletus elegans Schumacher, Enum. Pl. Saell. 2:374. 1803, nom. illeg., non Boletus elegans Bolton 1788. Cricunopus elegans P. Karsten, Rev. Mycol. 3:16. 1881. - Suillus elegans (P. Karsten) Snell in Slipp \& Snell, Lloydia 7:27. 1944. - Type: not designated.

Pileus 5-16(-22) cm, pale lemon yellow, yellow, golden, apricot or greyish ochre brown (the variation in colour is well presented by Kallenbach 1928: plate 17). Young pileus hemispheric, adhering by the margins to the annulus which tightly covers the tubes. Mature pileus with thick context in the centre, gradually convex, thin at the sharp margins, becoming essentially plane with age. Pileipellis with thick layer of slime, viscid when wet, slightly shiny when dry, easily removed when fresh. Stipe 5-15 $\mathrm{cm}$ long, 1.5-3.5 cm thick, essentially equal, viscid; with thick, floccose, and gelatinous annulus, which when young is white or partly yellow, and with age faded. The colour of stipe is similar to that of the pileus, with dense reddishbrown variegation or dots, yellowish-white at the base, above the annulus yellow, often with reddish-brown variegation or dots. Tubes yellow, subdecurrent to decurrent, 6-12 $\mathrm{mm}$ long. Pores small and dense, when cut or bruised becoming light greyish brown, darkening to rust-brown. Context light yellow to reddish-yellow, in the stipe reddish yellow to flushed brown, especially at the base; essentially soft and loose. Both the taste and scent are mild. Spore-print ochre to sienna. Spores smooth, very pale fulvous, pale straw-colour or nearly hyaline, ellipsoid, 7-10 $\mathrm{x}$ 3-4 $\mu \mathrm{m}$; colour of a few spores stronger fulvous, some with small reddish-brown granules inside. Length/width ratio of the spores 2.3-3.0, volume
34-74 $\mu \mathrm{m}^{3}$, average $52 \mu \mathrm{m}^{3}$. Caulobasidia are present far down on the stipe; see drawings by Sutara (1987). Cheilocystidia are numerous, mainly in bundles, cylindric to narrowly clavate or fusiform, fulvous, partly encrusted. Pileipellis with gelatinized intermixed hyphae, they are mostly hyaline or nearly so, with some small dark colour particles in a gelatinised matrix, end cells 3-8 x 30-80 $\mu \mathrm{m}$.

\section{Nomenclature}

The correct name of Suillus grevillei has been discussed by several authors during the past ten years. For instance, Alessio (1985) called it $S$. elegans and Šutara (1987) S. flavus. Likewise Breitenbach and Kränzlin (1991) wondered wether S. elegans should be adopted. However, as indicated by Palm and Stewart (1986), S. grevillei must be interpreted as a name sanctioned by E. Fries - though is lacking in the list of sanctioned names by Gams (1984) - and it thus definitely overrides the other two, earlier names. In addition, Boletus elegans Schumacher 1803 , always regarded as the basionym of $S$. elegans, is an illegitimate later homonym and cannot act as a basionym at all; apparently only in 1878 was the epithet elegans used in another combination, Cricunopus elegans P. Karsten, which is the legitimate basionym to be cited according to Art. 72, Note in the present code. $S$. flavus probably really refers to this species, as typified by Dörfelt (1984), though the identity of the type (illustration) is doubted by Palm and Stewart (1984); in any event, Boletus flavus has been much misused earlier.

\section{Distribution and ecology}

Suillus grevillei has a very wide distribution in Europe and more generally within the range of Larix in the whole Northern Hemisphere, reaching the polar timberline in the north (e.g. Vasil'kov 1955: 21, Smith \& Thiers 1964, 1971, Singer 1965, Kallio \& Heikkilä 1992). It closely follows various Larix species, both native and cultivated, and can be found even under single planted trees in parks far outside the natural range. For example, in Iceland, where Larix has been planted extensively, S. grevillei has become one of the major wild edible mushrooms (Thors 1991). 
Traditionally $S$. grevillei has been recognized as an obligate mycorrhizal partner of Larix, though it has sometimes been reported forming mycorrhiza with other trees. For example, in southern Finland (Lapinjärvi) it is associated with planted Pseudotsuga menziesii (Mirb.) Franco (Korhonen 1991).

Suillus grevillei fruits early in southern Finland, of starting in July and continuing until the first part of October. It produces basidiomes fairly regularly annually, and in large quantities. Accordingly it is a favourite of mushroom pickers.

\section{Suillus clintonianus - Figs. 3, 4, 5e-h, 6}

Suillus clintonianus (Peck) Kuntze, Rev. Gen. Pl. 3:535. 1898. - Boletus clintonianus Peck, Ann. Rep. Reg. State New York 23 (app. C): 128, pl. 5. 1872 ('1873’). — Suillus grevillei var. clintonianus (Peck) Singer, Lilloa 22:657. 1951 ('1949'). - Boletinus grevillei var. clintonianus (Peck) Pomerleau, Fl. Champ. Québec 429. 1980, nom. inval. - Type: U.S.A. New York. Genesee Co.: North Elba, Peck (NYS! holotype).

Ixocomus grevillei f. badius Singer, Rev. Mycol. 3:40. 1938. - Suillus grevillei f. badius (Singer) Singer, Pilze Mitteleur. 5(1): 66. 1965. - Suillus grevillei var. badius (Singer) Watling, Brit. Fungus Fl. 1:68. 1970, nom. inval.; (Singer) Kallio in Ulvinen, Suursieniopas 46. 1976, nom. inval.; (Singer) Kallio \& Heikkilä in Hansen \& Knudsen, Nordic macromyc. 2:70. 1992, nom. inval. - Type: Russia. Gorno-Altai Republic, Chuyskie Alps, 1937 Singer \& Vasil'eva 511 (LE 4698!, apparent syntype).

Illustrations: Peck (1873: plate 5, as Boletus clintonianus), Miller (1978: photo 285, as S. grevillei), Korhonen (1992, as $S$. grevillei var. badius).

Pileus 5-16 cm, reddish-brown, dark reddish-brown, dark chestnut-brown, exceptionally some yellow colour on the disc centre. Colour dark when young, the intensity remaining essentially unchanged with age. Young pileus hemispheric, adhering at the margins to the annulus, which initially covers the tubes. Mature pileus with thick context in the centre, high convex, thin at the sharp margins, becoming essentially plane with age. Pileipellis with thick layer of slime in rain, viscid when wet, shiny when dry. Stipe 5-15 cm long, 1.5-2.5 cm thick, essentially equal, viscid; with floccose, soft and slightly gelatinous annulus, which is light yellow below, with reddish-brown gelatinous ring by the upper margin, inner surface light yellow, yellowish-white. With age the annulus becomes thin, fading to become viscid on the surface of the stipe. Stipe is yellow with dense reddishbrown variegation or dots, yellowish-white at the base, yellow above the annulus, often with reddish-brown variegation. Tubes light yellowishorange with rusty tinge, colour more intense when young, decurrent to long decurrent, 6-10 $\mathrm{mm}$ long. Pores small and dense, when cut or bruised becoming light greyish-brown, darkening to rust-brown. Context light orangeyellow, in the stipe light brown to flushed rustbrown, at the base accosionally becoming bluish; especially in mature caps soft. Taste and scent are mild. Spore-print ochre to sienna. Spores ellipsoid, smooth, pale straw-colour, pale fulvous or nearly hyaline, but fairly often also pale reddish-brown, with small red-brown granules granules inside, $8.5-12 \times 3.5-4.5 \mu \mathrm{m}$, length/ width ratio $2.2-3.0$, volume $47-125 \mu^{3}$, average $83 \mu \mathrm{m}^{3}$. Caulobasidia are present down on the stipe, as in S. grevillei. Cheilocystidia are cylindric to clavate or fusiform, fulvous, separate or in fascicles, and are incrusted. Caulocystidia in fascicles, fulvous brown, incrusted. In tube trama among hyaline hyphae there are a few brown-yellowish lactiferous-like hyphae. Pileipellis with both gelatinous hyaline hyphae and abundant gelatinous hyphae with incrusting dark-brown-material, and with numerous dark red-brown colour particles in a gelatinised matrix; end cells 5-10 x 35-110 $\mu \mathrm{m}$.

\section{Nomenclature}

Suillus clintonianus was earlier much used in North America for S. grevillei coll., but for a long time now it has not been recognized, except sometimes as a variety of $S$. grevillei. In Europe, especially Finland, the name $S$. grevillei "var. badius" has been used for the same taxon (e.g. Kallio 1976), though the combination has probably never been published validly.

\section{Distribution and ecology}

In Finland, Suillus clintonianus has been recorded in many provinces, from the south to the north. It is more common in northern Finland, in some regions even more so than $S$. grevillei. In southern Finland it has been reported from only a few localities. Everywhere it is associated with 

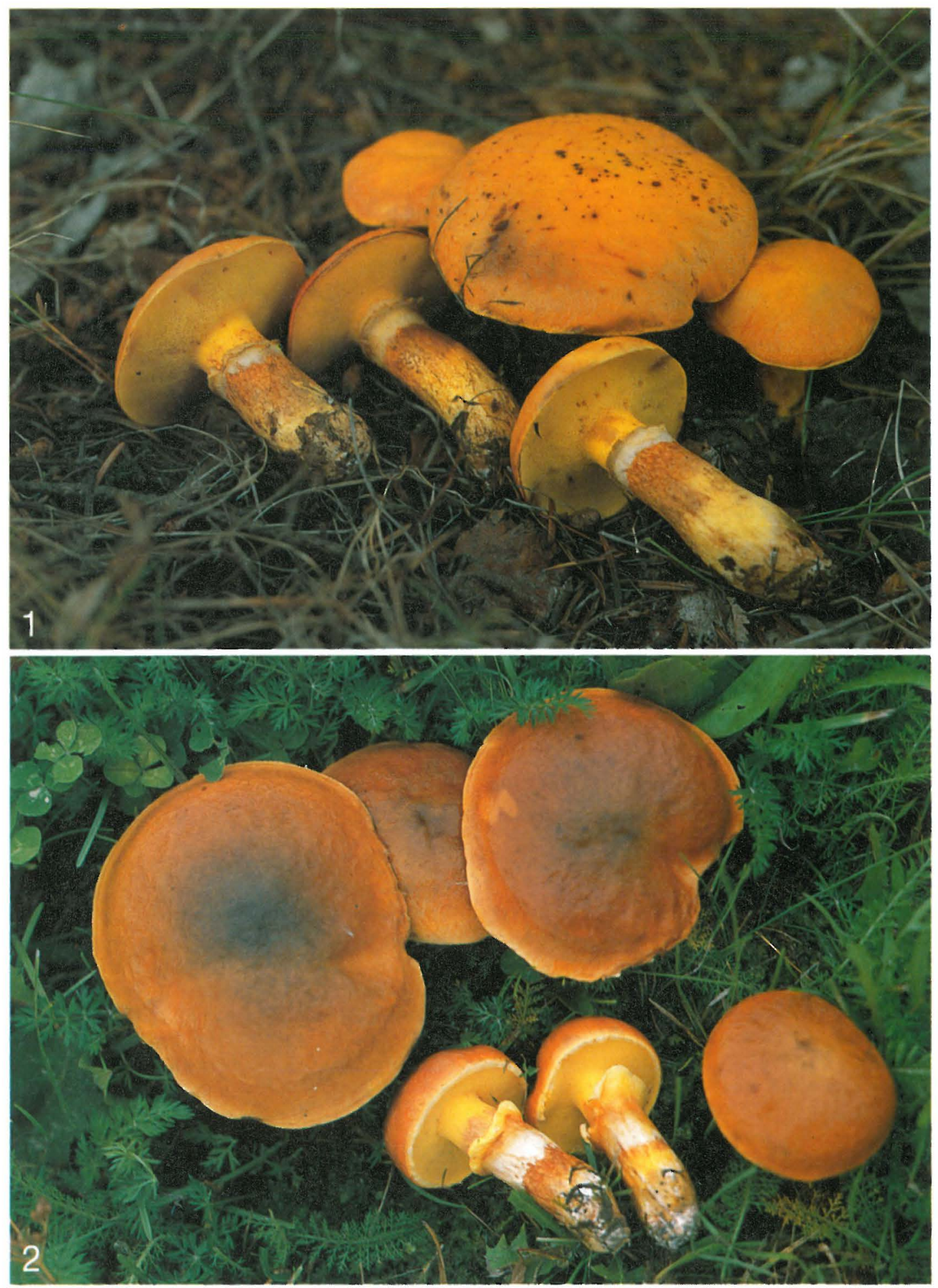

Figs. 1-2. Suillus grevillei. - 1: yellow ("normal") variant. Finland, Uusimaa, Lapinjärvi, 1989 Korhonen 9626 (H). 2: ochraceous variant. Finland, Perä-Pohjanmaa, Tornio, Kalkkimaa, 1988 Korhonen 8482 (H). — Photos: Mauri Korhonen. 

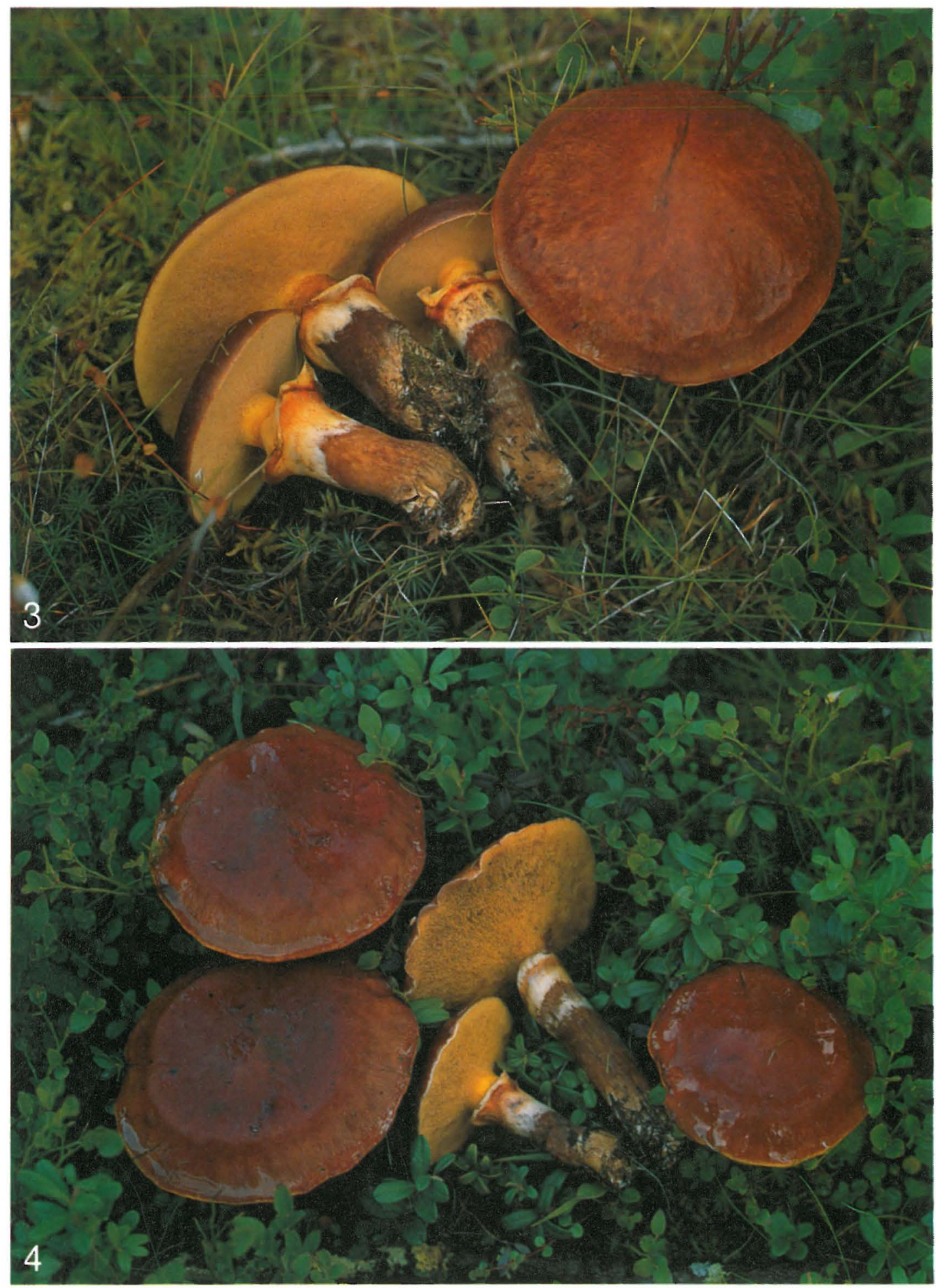

Figs. 3-4. Suillus clintonianus. - 3: Finland, Perä-Pohjanmaa, Rovaniemi parish, Vanttauskoski 1990 Korhonen 9634 (H). - 4: Finland, Korhonen 8570. — Photos: Mauri Korhonen. 

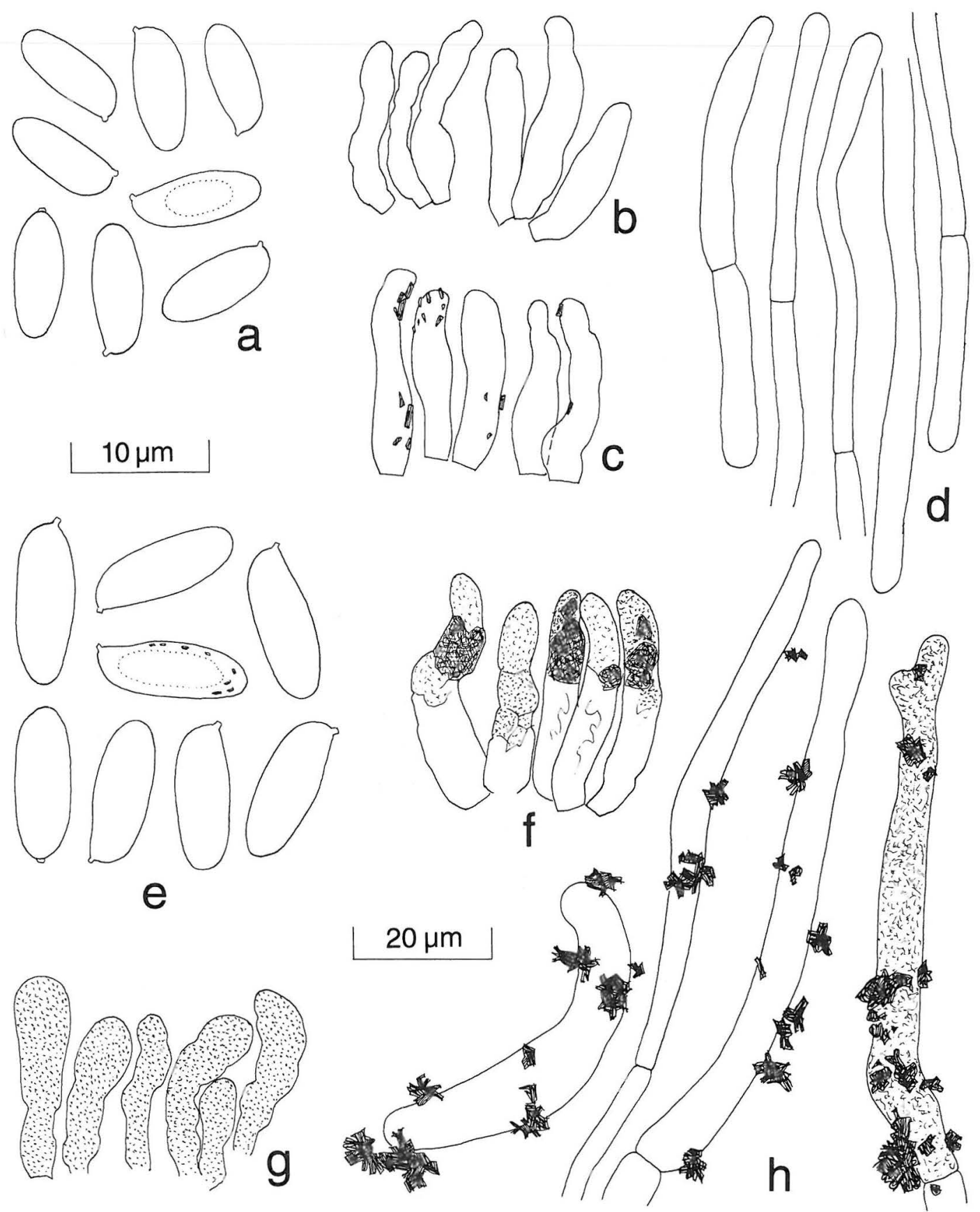

Fig. 5a-h. - a-d. Suillus grevillei (Finland, Rovaniemi parish, Vanttauskoski, 1990 Korhonen 9653, H). a: spores, b: cheilocystidia, c: caulocystidia and d: hyphae of pileipellis. - e-h. S. clintonianus (1956 Tuomikoski). e: spores, f: cheilocystidia, g: caulocystidia and h: hyphae of pileipellis. - Scale of spores x 2000 ; other elements $\times 1000$. 
planted Larix spp., normally with Larix sibirica Ledeb. (syn. L. russica (Endl.) Sabine ex Trautv.), which is a very frequent cultivated (never native) tree in Finland (Hämet-Ahti et al. 1992). Perhaps the majority of the Larix sibirica stands derive from provenances introduced from an old plantation at Roshchino (Raivola), NW of St. Petersburg. For instance, 10000 young Larix trees were transplanted to Liimatta, near Vyborg (Viipuri) in 1887 (Thesleff 1920), and transplants of those trees later made their way to places all over Finland. Accompanying those 10 000 trees, undoubtedly, were the mycorrhizal fungi of Larix, among them S. clintonianus, since this species had been collected by Thesleff at Roshchino. In Scandinavia, S. clintonianus has been recorded only in Finland and Sweden. There are no records from Norway or Denmark (Kallio \& Heikkilä 1992). However, in Denmark, Norway and Sweden Larix sibirica is not commonly planted, but instead the Central European L. decidua.

Suillus clintonianus has occasionally been found in the British Isles (Watling 1970), but with the hybrid larch $L . \mathrm{x}$ marschlinsii Coaz ( $L$. $\mathrm{x}$ eurolepis A. Henry) (R. Watling, in litt.). One locality has been reported from the Faroe Islands and two from the Alps, Switzerland (M.E.
Noordeloos, pers. comm.). The taxon $S$. clintonianus actually appears to have a circumpolar distribution. It is found even at the northern timberline, always associated with Larix, being common in the extensive native Larix forests of northern Russia and Siberia, and especially in the eastern parts (K. Kalamees, pers. comm.). The range extends southward along the mountains, and it has been found in the Ural and Altai Mts. and in China. There it is associated with several species of Larix, though primarily with $L$. sibirica and $L$. gmelinii. It is common in North America - in the eastern parts of the continent less common than S. grevillei, while in western parts it may be even more common (Slipp \& Snell 1944, Miller 1978).

The fruiting period is like that of S. grevillei, from July to September, and on the south coast of Finland extending into early October.

\section{Discussion}

Macroscopically, Suillus clintonianus is most easily distinguished from $S$. grevillei by its dark reddish-brown pileus. The colour of $S$. greville $i$ varies widely but darkest hues are attained only by old pilei, when they are greyish ochre-brown.

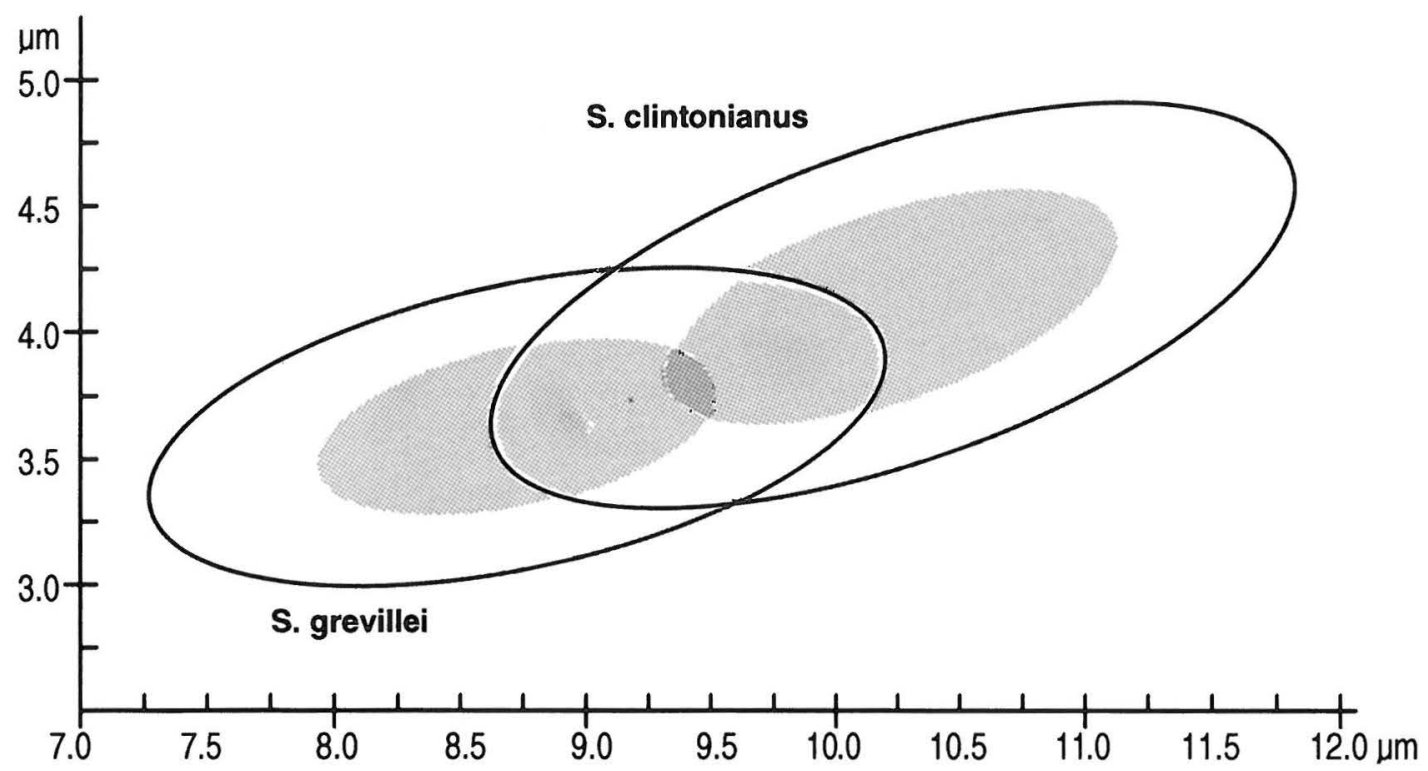

Fig. 6. Diagram showing the spore size difference of Suillus grevillei and S. clintonianus. The lines are drawn on the basis of scatter diagrams and embrace ca. $95 \%$ of the spores measured of each species. $80 \%$ of all the measured spores of each species lie in the darkened areas ( $S$. grevillei, 770 spores, 21 specimens; $S$. clintonianus, 885 spores, 24 specimens); $x-$ axis, length of spores; $y$-axis, width of spores. 
By contrast, $S$. clintonianus may become lighter with age. There is also a some difference in the colour of the pores, those of $S$. clintonianus being yellowish-orange with rust-coloured hue, while $S$. grevillei has yellow pores and tubes. The clearest differences are seen only in a close study of the microscopical features, however. The hyphae of the pileipellis are hyaline in $S$. grevillei and mainly encrusted in S. clintonianus (Fig. 5). The spores are smaller (average volume $52 \mu \mathrm{m}^{3}$ ) in. S. grevillei than in S. clintonianus (average volume $83 \mu \mathrm{m}^{3}$ ).

\section{Representative specimens examined:}

Canada. Ontario: Ottawa, Highfield Crescent, 1966 Groves (H ex DAOM 115344). Québec: La Verendrye, Lac des Loups, 1963 Pantidou \& Elliott (H ex DAOM 93205); Tourville, 1966 Groves 66-72 (H ex DAOM 115327). U.S.A. Idaho: Payette National Forest, near road to Brundge Mt., 1975 Miller 15052 (VPI). Sweden. Västmanland: Skinnkatteberg, Riddarhyttan, 1983 Kytövuori $83557(\mathrm{H})$. Västerbotten: Umeå, Södra Bäcksjön, 1987 Olofsson (UME). Finland. Varsinais-Suomi: Paimio, Preitilä, 1985 Mäkinen \& Laine 85-977 (TUR); Tammisaari, Bromarv, Solböle, 1990 Korhonen 10002 (H). Uusimaa: Porvoo parish, Vessö, 1930 Nyberg (H). Etelä-Häme: Lammi, Evo, 1956 Tuomikoski (H), 1975 Korhonen 1434 (H). Etelä-Savo: Punkaharju, 1990 Korhonen 9602 (H). Pohjois-Häme: Ähtäri, 1970 A. \& K. Pohjola (TUR). Pohjois-Karjala: Kitee, Puhos, 1978 Korhonen \& Tuomikoski 2228 (H). Oulun Pohjanmaa: Pudasjärvi, Kurenala, 1965 Ahti 20015 (H). Perä-Pohjanmaa: Rovaniemi parish, Muurola, 1991 Vauras 5799 (TURA); Vanttauskoski, 1988 Korhonen 8570, 1990 Korhonen 9626 (H). Koillismaa: Kuusamo, 1989 Ahti $48504(\mathrm{H})$. Inarin Lappi: Inari, Toivoniemi, 1968 Kallio (TUR). Faroe Islands. Streymøy: Tórshavn, Gundadalur Plantation, 1988 Petersen et al. (C). Russia. Amur Region: Nikolaevsknana-Amure, 1906 Shestukhov (LE 158903). Bashkortostan: Bashkirian State Reserve, Alakbar Mtn, 780 m, 1953 Selivanova-Gorodkova 491 (LE 4715). Gorno-Altai Rep.: Chuyskie Alps, 1937 Singer \& Vasil'eva 593 (LE 17804), Akturu, 1937 Singer \& Vasil' eva 511 a (LE 4700). Irkutsk Region: Listvenichnoe, 1947 Vasil'kov (LE 4701, 4704, 4705, 4707, 17806); Slyuden District, Vydrino Sta., 1981 Petrov (LE 4706). Krasnoyarsk Territory: Sayan-Shushenskiy Reserve, Sarla R., 1984 Kovalenko 84-8-8 (LE 4693). Leningrad Region: Roshchino (Raivola), 1892 Thesleff (H). Tyumen' Region: Labytnangi, 1962 Vasil kov (LE 4691).

Acknowledgements. We thank the curators of the herbaria, especially of LE and NYS, for placing specimens at our disposal. Useful information was received from Dr. Harri Harmaja (Helsinki), Dr. O.K. Miller (Blacksburg, VA), Dr. Seppo Huhtinen (Turku), Prof. Kuulo Kalamees (Tartu), Dr. Ilkka Kytövuori (Helsinki), Dr. M.E. Noordeloos
(Leiden), Mr. Olle Persson (Stockholm), the late Prof. Risto Tuomikoski, Mr.Tauno Ulvinen (Oulu) and Dr. Roy Watling (Edinburgh). Ms. Kay Ahonen revised the English.

\section{References}

Alessio, C.L. 1985: Boletus. Fungi europaei 2. - 712 pp. Biella Giovanna, Saronno.

Breitenbach, J. \& Kränzlin, F. 1991: Fungi of Switzerland. 3. - 361 pp. Edition Mykologia, Lucerne.

Dörfelt, H. 1984: Über einige Pilznamen. - Boletus 2:60-64.

Gams, W. 1984: An index to fungal names and epithets sanctioned by Persoon and Fries. - Mycotaxon 19:219-270.

Hämet-Ahti L., Palmén, A., Alanko, P. \& Tigerstedt, P.M.A. 1992: Suomen puu- ja pensaskasvio. Ed. 2. 373 pp. Dendrologian Seura, Helsinki.

Kallenbach, F. 1928: Die Pilze Mitteleuropas I. Die Röhrlinge. 6. - Klinkhardt, Leipzig.

Kallio, P. 1976: Tatit - Boletaceae. In: Ulvinen. T. (ed.), Suursieniopas: 37-49. - Suomen Sieniseura, Helsinki.

Kallio, P. \& Heikkilä, H. 1992: Gomphidiaceae. In: Hansen, L. \& Knudsen, H. (eds.), Nordic macromycetes 2:68-71. - Nordsvamp, Copenhagen.

Korhonen, M. 1991: Vuoden suurin sieni 1990. — Sienilehti 43:3-5.

Korhonen, M. 1992: Suillus grevillei var. badius. Sienilehti 44:110 \& 144 (back cover).

Miller, O.K. 1978: Mushrooms of North America. - 368 pp. E.P. Dutton, New York.

Palm, M.E. \& Stewart, E.L. 1984: On the typification of Suillus (Boletaceae, Basidiomycotina). - Taxon 33:711-712.

Palm, M.E. \& Stewart, E.L. 1986: Typification and nomenclature of selected Suillus species. - Mycologia 78:325-333.

Peck, C.H. 1872('1873'): Report of the botanist. - Ann. Rep. Reg. State New York 23 (app. C): 27-135.

Pegler, N.D. \& Young, T.W.K. 1981: A natural arrangement of the Boletales, with reference to spore morphology. — Trans. British Mycol. Soc. 76:103-146.

Singer, R. 1965: Die Pilze Mitteleuropas V. Die Röhrlinge I. - 131 pp. Klinkhardt, Bad Heilbrunn.

Slipp, A.W. \& Snell, W.H. 1944: Taxonomic-ecologic studies of the Boletaceae in Northern Idaho and adjacent Washington. - Lloydia 7:1-66.

Smith, A.H. \& Thiers, H.D. 1964: A contribution toward a monograph of North American species of Suillus. 116 pp. Ann Arbor, MI.

Smith, A.H. \& Thiers, H.D. 1971: The boletes of Michigan. - 428 pp. Univ. Michigan Press, Ann Arbor, MI.

Š utara, J. 1987: The limit between the genera Boletinus and Suillus. - Ceská Mykol. 41:139-152.

Thesleff, A. 1920: Studier öfver basidsvampfloran i sydöstra Finland. - Bidr. Kännedom Finlands Natur Folk 79(1): 1-140.

Thors, B. 1991: Finns det verkligen svampar på Island? Sienilehti 43:16-18. 
Vasil'kov, V.P. 1955: Ocherk geograficheskogo rasprostraneniya shlyapochnykh gribov v SSSR. - 88 pp. Izd. Akad. Nauk SSSR, Moskva \& Leningrad.

Watling, R. 1970: Boletaceae: Gomphidiaceae: Paxil- laceae. British fungus flora 1. - 126 pp. Royal Bot. Garden, Edinburgh.

Received on 15 January 1993 